
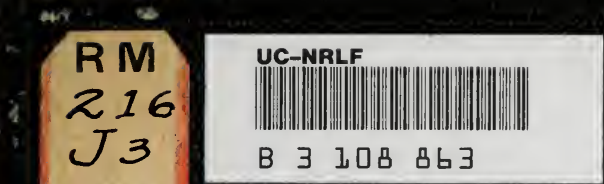

\title{
THE STUDY OF
}

Human Foods and Practical Dietetics

BY M. E JAFFA, FH, B, 

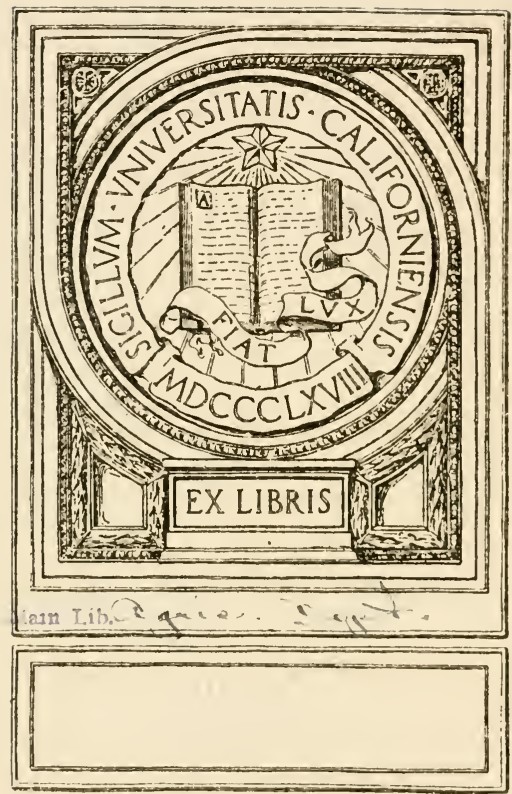
-

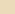

-

,

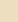



Digitized by the Internet Archive in 2008 with funding from Microsoft Corporation 
UNIVERSITY OF CALIFORNIA AGRICULTURAL EXPERIMENT STATION.

BERKELET, CAL.

E. W. HILGARD, Director.

BULLETIN No. 110.

\section{THE STUDI}

OF

\section{HUNAN FOODS AND PRACTICAL DIETERTICSS.}

BY MI. E. JAFFA, PH.B.

FEBRUARY, 1896.

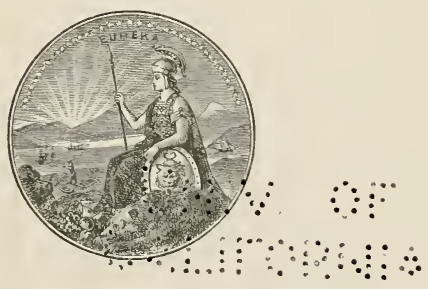

S A C R A M ENTO:

A. J. JohNSTon, : : : : : : SUPERINTENDENT StATE PRINTING. 1896. 
$$
\text { To } 801212
$$$$
\text { S } 3
$$$$
\text { Lime }
$$

anir til.

ayr.c leent. 


\section{THE STUDY OF HUMAN FOODS AND PRACTICAL DIETETICS.}

By M. E. JAFFA.

[This bulletin may be considered as the sequel and natural complement of Mr. Jaffa's bulletin on "The Cattle Foods of California," No. 100, published in 1893. This latter excited a great deal of interest and is still frequently called for by dairymen and others, showing that it supplied needed information. It would seem that a similar discussion of human foods is at least as much called for at a time when not only hygienic questions but also that of economy are forcing themselves upon public notice. The present paper was originally written and delivered as a lecture to the University Science Association, exciting a good deal of discussion and interest at the time; with so many subsequent applications for the tables that the small edition prepared will soon be exhausted. While not laying claim to originality save in the arrangement of tables convenient for reference and use in the selection of dietaries, together with some data supplied by recent work done at this Station in the analyses of fruits and nuts, it is thought that this compact and easily intelligible presentation of the subject of human dietaries will commend itself to public attention, and may help to rectify some of the incorrect practices and views now so largely prevalent in respect to the principles upon which human nutrition should be based under the varied conditions of modern life.-E. W. H.]

The study of human foods has only recently begun to receive the attention that the importance of the subject demands. Up to fifty years ago little was known either of the composition of the human body or of the materials used as food. Since that time thorough scientific investigation has been inaugurated and the progress has been rapid. As is usually the case in all matters of scientific research, Germany took the lead, and the writings of Liebig, first published in 1842, may be considered as pioneer work. Some idea of the amount of chemical work done in Europe alone may be gained by noting that the first edition of Dietrich and Konig's compilation of analyses of feeding stuffs, published in 1874, is a thin volume of 100 pages, while the second edition, seventeen years later, is in two volumes containing 1,400 pages.

We are indebted chiefly, for the results we have in this country, to Professor Atwater, Director of the Storrs (Conn.) Agricultural Experiment Station and Special Agent of the United States Department of Agriculture; and he deserves the greatest praise for his persistent and patient efforts in inaugurating this kind of research in the United States.

When his investigations were first undertaken, and for about twelve years subsequently, most of the funds required were furnished by private parties and sometimes by Professor Atwater himself. This is one of the cases where the persistent efforts of private parties have proved so conclusively to the Government the importance and necessity of the work done, that it has felt in duty bound to financially help the cause. Last year a considerable sum was appropriated to carry on the work outlined by Professor Atwater, and he was appointed agent in charge. It is to be sincerely hoped that our Station will soon be in a position to help in the great movement which has secured such a firm footing in some parts of the East. 
But no one country can work aut these problems for the world; there are important differences in each country - in environment, in habits of food consumption, and in the nature and composition of availahle foodstuffs - that need special investigation for each. Thus far, in the United States much more work has been done in the line of cattle foods than in human foods.

Investigations of cattle foods have been carried on for about thirty years, and the results are in practical use all over the country. There is searcely a dairyman worthy of the name who does not try to feed his cattle in a rational, scientific, and economic manner. He is guided in his efforts by the results of scientific investigations at the various Agricultural Experiment Stations; in fact, all animal feeders are now looking to these stations for trustworthy guidance in this direction, and thus much practical good has been accomplished in a few years. The dairyman realizes that in order to get the greatest quantity of good milk from his cows he must give them a sufficient amount of the materials necessary for its production. He is not actuated by motive of philanthropy, for he knows he can thus get the largest return for his outlay, and that his animals will do enough better work to compensate him for the trouble and expense.

Why can we not look upon the feeding of human beings in the same practical way? How long will we continue to eat merely to satisfy our hunger-eating anything that comes in our way, anything that pleases our taste, without regard to special conditions or special needs? And yet this is what the large majority of people do. How many men are there in the ordinary walks of life who give even a passing thought to the character of food they require-whether more nitrogenous or starchy, or, indeed, even as to how much they need to keep them in a vigorous, healthy condition. How many of us who are even in the midst of chemical research, and who dwell in an intellectual atmosphere, give any attention to the subject of eating, or make any attempt to regulate our diet according to the scientific data at our command. The caus's of this neglect are twofold: First, our natural conservatism prompti us to continue to eat what we always have eaten; and second, we are ignorant both of the kinds and composition of the food neeled and the required relative quantity of each.

Sir Henry Thompson, a noted English physician, says: "I have come to the conclusion that more than one-half the discase which embitters the middle and latter part of life, is due to avoidable errors in dict, * * and that more mischief in the form of actual disease, of impaired vigor, and of shortened life, acerues to civilized man * * * in lingland and throughout Central Europe from erromeous habits of eating than from the habitual use of alcoholic drink, considerable as I know that evil to be."

But new as the food question is, we certainly have already sufliciont reliable data with which to make a beginning, and it is the object of this paper to give a brief survey of the subject, and to point out to those whose work doces not bring them inte toueh with this line of thonght, a few of the main points and simple rules of practical feeding.

This paper is, then, presented to the publie with the hope that it may help to popularize the long-neglected hut important suhject of seientific ferding. All unnecessary details have becon omitted in order to make the suljoet as elear as possible to those to whom it may be new; and 
the tables have been arranged so that they may be most easily used by any who are unaccustomed to such work.

Before proceeding with the study of dietaries it may not be out of place to give a brief resumé of the first principles, the A B C's, as it were, of the subject, $i$. $e$, the objects of feeding-the chemical composition of the various parts of the body; and also the classes of foodstuffs, with the offices the different ones perform in the body.

\section{OBJECTS OF FOOD.}

We all know that the young body, animal or human, requires food to supply the material necessary for its growth. But beyond this, and continuing during and past the growing stage, there is a current wearing-out and breaking-down of all the various tissues of the body. This loss must be supplied in order to keep the animal in a normal, healthy condition. Not only must the worn-out tissue be replaced, but the material, used as fuel in producing the energy necessary for carrying on all voluntary and involuntary functions, must also be supplied. A man who is doing hard physical work is using up a great deal of fatty tissue, as well as muscle; but a man who is doing nothing (making no voluntary exertion), also experiences a loss of tissue through the constant production of the heat necessary for the maintenance of the normal body temperature, and also for the performance of all the involuntary functions of the body. Hence we might summarize the objects of feeding as follows:

1. To build up and maintain the body in its normal condition.

2. To serve as a fuel-supply to be consumed in the body, producing heat to keep it warm, or the energy (muscular or otherwise) necessary for the performance of work.

3. To be stored for future use.

COMPOSITION OF FOODS.

In order to see how these objects may best be carried out, we must understand the composition of these tissues that need rebuilding, and also the composition of the various foodstuffs at our command. Viewing them side by side for the purpose of better comparison, we see, from a general analysis, that each is composed of the same four main ingredients-water, mineral matters, nitrogenous and non-nitrogenous material.

Water.- Water constitutes about two thirds of the weight of the body, and enters into the composition of all its tissues and fluids. As it does not form nearly that large a proportion of our ordinary cooked foods, we can readily understand the necessity of its use as a separate part of our diet.

Mineral Matters.-The mineral matter comprises about 5 per cent of the body, and has important functions to perform, such as entering into the formation of the bones and teeth, regulating the density and taking part in the functions of the blood and such other fluids of the body, as the bile, juices of the stomach, etc. In estimating food-values, the mineral or inorganic ingredients are generally omitted, not on account of any lack of importance of that portion of our food, but for the reason 
that nearly all foods, no matter of what description, contain a sufficient amount of these substances, which comprise, mainly, lime, potash, and phosphoric acid, with varying quantities of sodium, iron, magnesia, sulphuric acid, hydrochloric acid, silica, etc.

Nitrogenous, or Proteids.-The nitrogenous matters of the body, of which the major part are called proteids, the only ones that contain nitrogen, are found mostly in the muscle, gelatinous part of the bones and tendons, brain, nerves, and internal organs; in short, all the working machinery of the body is composed principally of this important material. Similarly, in the foods, almost the entire nitrogenous part is called protein, signifying, by its Greek derivation, to take first place. We receive the protein from the white of egg, the myosin of lean meat, cascin of milk, gluten of wheat, gelatinous parts of bones, tendons, ete.

The necessity of this constituent in the daily diet depends not only upon its important relation to such tissues as muscle, blood, nerves, tendons, ete., but also upon the fact that as far as we know no albuminoid or protein matter is formed in the body, except by the transformation of similar substances presented to it from external sources. It cannot be obtained by the conversion of any other material.

The protein can be changed into fats, and thus may serve as fuel for the body, but fats cannot replace protein.

Non-nitrogenous, or Carbohydrates and Fats.-The non-nitrogeneous portions of the solid constituents of the body are principally fat-the material which is consumed in the production of heat and energy. The source of this substance in foodstuffs is comprised in all those portions which are free from nitrogen. They are divided into two main classesthe carbohydrates and fats-and are identical with those found in the body, with the exception of starch and sugar, which are not found as such in any large amount in the healthy body.

The carbohydrates comprise starch, sugars, gums, and wooly fiber; the latter, in the statement of analyses of foods, is reported separately, while the remainder of the above are, in order to conform to the gencral usage, elassed together under the head of "nitrogen-free extraet." The gums play only a secondlary part as regards the nutritive value of the food. The carbohydrates are mostly changed into fats and then meed as fucl; although it must be remembered that, for the purpose of heat, fat is worth 2.25 times as much as carbohydrates, that is, 1 pound of fat is equivalent, when used as fuel, to 2.25 pounds of stareh, sugar, cte. When there is a deficieney of these elements in the food, the fat of the body is drawn upon.

The fat, as might be supposed, varies more than any other substanee of the body, its aecumulation being regulated liy diet, museular exereise, ete. Slecp, as well as inactivity, favors the storage of fat, which in the average body constitutes 20 per cent of the total weight.

If the food-supply is cut off, the surplus fat stored up in the lonly is drawn upon to keep the mathinery going, and if this continues a corresponding amount of protein is converted into fat and used als such. Thus we see that by having a proper proportion of fat in our ford we protect not only the fat of the body, but indirectly, and most important, the protein of the muscle and lifool. We receive our fat from such foods as the butter of milk, fat of meaf, oil of seeds and fruits such as 
the olive, wax of plants, etc. The fats of herbaceous vegetables have less value than those of seeds and fruits.

\section{DIGESTIBILITY OF FOODS.}

Upon the basis of the preceding we can proceed intelligently with the next step, which is to consider the digestibility of the different foods. If the total amount of each food introduced into the body was digestible, the whole subject of feeding would be very much simplified. But, on the contrary, in all foods there is a certain portion of each nutrient, whether it be protein, fat, or carbohydrate, which is not digested or assimilated. A large number of experiments have been made in this direction, most of them in Germany.

In order to ascertain how much of the food is not digested, the food is weighed and analyzed before consumption, and the weight and conposition of the excrement is also determined.

The difference between the two analyses is taken as the quantity digested or assimilated. The results so obtained are termed digestion co-efficients, and are only approximate, but in the present state of such researches, they are the best data available. Besides these direct experiments on the body, others have been made in the laboratory with success, in which the gastric juice derived from animals has been employed. This cannot be so easily done in the case of man, as the normal gastric juice from human subjects is not ordinarily obtainable.

An animal can be fed on one kind of food for a given time and suffer no inconveniences in any way whatever, and, in all probability, would relish it. Quite the contrary would be the case with man. The most palatable food would, if fed alone, become exceedingly distasteful to him and tend to disarrange his digestive functions if fed for five or six days in succession; and thus, at the time when data on the digestibility and amount necessary of the food should be obtained, the system of the man might be in such a condition that the data would be unreliable. Again, for each food-material the digestion coefficient may vary considerably with different persons; still the more nitrogenous or easily soluble is the food, the higher, as a rule, is the digestion coefficient. Nearly all of the protein of ordinary meat, fish, and milk is readily digested; that of potatoes, whole wheat, and rye flour, one fourth or even one third may not be absorbed by the body. About 95 per cent of the fats from butter, milk, oils, and such foods is digestible. The vegetable fats vary from about 50 to 75 per cent; that is, the digestion coefficient would be from 50 to 75 . Sugar is supposed to be completely assimilated, and starch nearly so if not used in excess; these two comprise the main parts of the carbohydrates. The fruits and vegetables contain the bulk of the woody fiber.

The animal foods have in general the advantage of the vegetable, in that they contain more protein, and that their protein is more digestible. Professor Atwater states that the quantity of food digested appears to be less affected by flavors, flavoring materials, and food adjuncts, and to differ less with different persons than is commonly supposed.

Nutritive Ratio.-The different foods vary very much in their composition; some, such as peas and beans and the meats, contain large amounts of protein or muscle-forming ingredients, and very little of the 
non-nitrogenous materials; others, as the potato, rice, and some fruits, have chiefly starchy matter associated with small quantities of albuminoids; and again, as in the case of the regetables in gencral, we have small amounts of both earbohydrates and nitrogenous materials.

The proporition between the two important elements of our food is termed the nutritive ratio; or, in other words, it is the ratio of the digestible protein to the sum of the digestible portions of the remaining ingredients of the food. In estimating this remainder, the figure denoting the amount of fat is multiplied by 2.25 , because it has been ascertained by experiment, as before stated, that about 2.25 times as much heat is developed by the combustion of a pound of fat as is by the same quantity of carbohydrates. This product is added to the weight of the carbohydrates and the sum divided by the figure for the protein, the quotient being the nutritive ratio.

To illustrate, let us take wheat Hour, the analysis of which is as follows: Water, 12.50 per cent; protein, 8.00 per cent; fat, 1.10 per cent; and carbohydrates, 77.90 per cent. The fat percentage, 1.10 , multiplied by 2.25 , amounts to 2.48 ; this added to the figure for the carbohydrates, 77.90 , makes 80.38 , which divided by 8 , the per cent of protein, gives 10.05. Hence, the nutritive ratio is $1: 10$; in other words, there is in wheat flour one part of protein or nitrogenous matter to 10 parts of nonnitrogenous or starchy material. The ratio is "wide," and termed a carbonaceous one when the amount of protein to the remaining ingredients is small, as seen above. A "narrow" or nitrogenous ratio is one where the reverse is the case; that is, the amount of protein is large compared to that of the earbohydrates: as 1 of protein to about 4 or 5 uf sugar or starchy matters.

\section{DIETARIES.}

When speaking of cattle foods, the amount which is daily necessary to keep an animal in a healthy, satisfied condition is a ration. In diseussing human foods, the quantity required for daily consumption is termed a dietary, although both terms are in use. I well-balaneed diet is one in which the protein, or flesh-formers, and carbohydrates, or fatproducers, exist in the proper proportion. Usually we use foods or diets unbalaneed, in that they contain too much earbohydrates. In other words, we eat too much starch and fatty foods and an insufficient amount of nitrogenous or flesh-forming ingredients.

The dietary standards at our command have been worked out hy Voit in Germany, Playfair in England, Atwater in the Inited States, and others. The daily average for the different ingredients is about one quarter pound of protein, a thirel of a pound of fat, and a littlo over a pound of earbohydrates, making a nutritive ratio of $1: 5.8$, with a fuel value of alout 3,500$)$ calories.

Fuel l'alue.- By having the analyses of the different foxkls at our disposal, we would be able to ealenlate a cousiderable number of dicetaries; hut a somewhat simpler unethod is to use what is termed the fuel value of fools. 'This, as the name implies, is the heating power of the foxd. If we burn a piece of fat it will cenerate a certain amomut of heat, sol will a hmmp of sugar or stareh, of any otler ford-material. If this lieat were applied to water, it would warm it to a greater or loss

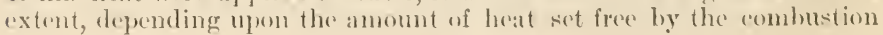


of the material in question. The unit of measurement of this heat is termed a calorie. A calorie is the amount of heat necessary to raise one kilogram of water $1^{\circ}$ centigrade, or one pound of water $4^{\circ}$ Fahr. The units of heat, or number of calories, contained in a given weight of the different food ingredients, have been very accurately ascertained by means of the calorimeter.

It would take up too much space to describe in detail the calorimeters which have been used in the analyses of foods. In general, the calorimeter consists of a vessel, bomb shaped according to the latest design, about $10 \mathrm{~cm}$. by $13 \mathrm{~cm}$; this bomb is immersed in a vessel containing two liters of water, which vessel is surrounded by an empty cylinder, enveloped in its turn by another empty vessel. As a protection to these, there is still another cylinder containing water; the outside of this cylinder is lined with a thick layer of felt. Hence, there is a layer of felt, one of water, and two of air between the calorimetric apparatus proper and the external air. The material to be burned is placed in a platinum capsule in the "bomb," and ignited in presence of compressed oxygen by means of an electric spark. A very finely graduated thermometer is connected with the vessel containing the two liters of water, and the heat imparted to the water and indicated by the thermometer, measures the fuel value of the food-material burned.

It has been found that, taking the ordinary foods as they are at our command-

One pound of protein yields 1,860 calories.

One pound of carbohydrates yields 1,860 calories.

One pound of fat yields 4,220 calories.

That is, the fuel value of fat is about 2.25 times that of either the starchy or the nitrogenous substances, as was stated when discussing the nutritive ratio.

Now, if a pound of fat is consumed by an animal it becomes a heatproducer; in other words, a slow combustion takes place, and the result is identical, as far as heat units are concerned, with that obtained by the calorimeter. This has been proved by means of respiration calorimeters, devised by some German investigators in this work, notably Drs. Rubner, Rosenthal, and Pettenkofer, of Munich, and they have obtained the same figures for the heat units in the nutrients of the food as those just given, viz.: 1,860 calories for protein and carbohydrates, and 4,220 calories for fat. Several different forms of respiration calorimeters have been tried with varying success. The best forms are those designed by Rubner and Rosenthal.

Rubner's respiration calorimeter consists of a metal box with double walls. In the interior are arrangements for keeping an animal, as in the ordinary respiration apparatus. Provision is made for conducting a current of air through this chamber and for measuring its amount and determining its composition.

In Rubner's apparatus the air in the double walls is allowed to expand and contract; and these changes, as shown by a manometer (pressure gauge), are the measure of the heat radiated from the body. In this case it is the increase or decrease of volume under constant pressure. In Rosenthal's apparatus, it is the variation of pressure from a constant volume. 
Dietary Standards.--Rubner, and others, also found that the fats and carbohydrates could replace each other in any dietary in the proportion: of 1 of fat to 2.25 of the starehy material, without altering the food value of the diet or ration. This being the case, we readily see why, if we know the protein or nitrogenous contents of the dietary and the fuel value in calories, we greatly simplify the caleulation, and at the same time the detailed eomposition of the dietary.

We must, howerer, know the amount of protein or albuminoids that is required, as the fuel value of a dietary affords no indication of the contents of this valuable and necessary element of our food. But, knowing this and the fuel value, we can choose from a number of food: dietaries which will be at the same time both nutritious and to our taste. In Table I are given some of the dietary standards worked out by Voit, Playfair, and Atwater. It must not be supposed that they are absolute, quite the contrary, but they are the results of researches up to the present time, and, as stated by Professor Atwater, more investigations in this all-important question are urgently called for.

TABLE $\mathrm{I}$.

Dietary Standards.

\begin{tabular}{|c|c|c|c|c|c|c|c|c|}
\hline & \multicolumn{2}{|c|}{ Protein. } & \multicolumn{2}{|c|}{ Fat. } & \multicolumn{2}{|c|}{ Carbohydrates. } & \multirow{2}{*}{$\begin{array}{l}\text { Fuel } \\
\text { Value } \\
\text { (Calo- } \\
\text { ries). }\end{array}$} & \multirow{2}{*}{$\begin{array}{l}\text { Sutri- } \\
\text { tive } \\
\text { Ratio. }\end{array}$} \\
\hline & Lbs. & Ozs. & Lbs. & Ozs. & Lbs. & Ozs. & & \\
\hline 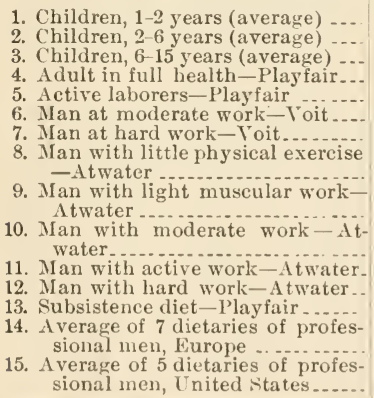 & $\begin{array}{l}.06 \\
.13 \\
.16 \\
.26 \\
.34 \\
.26 \\
.32 \\
.20 \\
.22 \\
.28 \\
.28 \\
.33 \\
.39 \\
.13 \\
.25 \\
.27\end{array}$ & $\begin{array}{l}1.00 \\
2.00 \\
2.61 \\
4.16 \\
5.44 \\
4.16 \\
5.12 \\
\\
3.20 \\
\\
3.52 \\
4.48 \\
5.28 \\
6.24 \\
2.00 \\
4.00 \\
\\
4.32\end{array}$ & $\begin{array}{l}.08 \\
.09 \\
.10 \\
.11 \\
.16 \\
.12 \\
.22 \\
.20 \\
.22 \\
.28 \\
.33 \\
.55 \\
.03 \\
.22 \\
.34\end{array}$ & $\begin{array}{r}1.31 \\
1.41 \\
1.52 \\
1.71 \\
2.56 \\
1.92 \\
3.52 \\
\\
3.20 \\
\\
3.52 \\
4.45 . \\
5.28 \\
8.80 \\
.50 \\
3.52 \\
\\
5.44\end{array}$ & $\begin{array}{r}.16 \\
.44 \\
.71 \\
1.17 \\
1.25 \\
1.10 \\
.99 \\
.66 \\
.77 \\
.99 \\
1.10 \\
1.43 \\
.75 \\
.63 \\
1.08\end{array}$ & $\begin{array}{r}2.61 \\
7.05 \\
11.46 \\
18.72 \\
20.00 \\
17.60 \\
15.84 \\
\\
10.56 \\
\\
12.32 \\
15.84 \\
17.60 \\
18.85 \\
12.02 \\
10.08 \\
17.28\end{array}$ & $\begin{array}{r}765 \\
1,420 \\
2,040 \\
3,140 \\
3,630 \\
3,055 \\
3,370 \\
2,450 \\
2,800 \\
3,520 \\
4,060 \\
5,700 \\
1,760 \\
2,670 \\
3,925\end{array}$ & $\begin{array}{l}5.6 \\
5.0 \\
5.2 \\
5.5 \\
4.7 \\
5.3 \\
4.7 \\
\\
5.5 \\
\\
5.7 \\
5.8 \\
5.6 \\
6.9 \\
6.3 \\
4.7 \\
\end{array}$ \\
\hline
\end{tabular}

An inspection of the table shows, first, that, naturally, the more physieal work a man does the larger amounts of food he requires; and secondly, that the American workman eonsumes more food than either the English or German laborer. This is best seen by comparing dietaries Nos. 5, 7, and 12. Similarly, from the limited data at hand it is noted by examining Nos. $1 . t$ and 15 that the profesional men of Eurepe do not eat as much as their Ameriean brethren.

On eomparing the fuel value of the several dietaries in this table we find that at rhild of from 1 to 2 years of age requires the minimum of 765 calories. When it is from "2 to (i years old, the food must have nearly twice the fuel value, or 1,420 calories; thence up to 15 years ford 
of 2,040 calories is demanded, while for an adult in full health the fuel value must be increased to 3,520 calories.

A man at hard work naturally requires the maximum amount of food, which, on an average, must represent a fuel value of 5,700 calories.

Nos. 14 and 15 are not really dietary standards, but, as stated, are the average of the respective number of dietaries mentioned, and are inserted in the table for comparison only. In the case of children, Nos. 1,2 , and 3 , it will be seen that the protein or nitrogenous part and the carbohydrates of the food increase very rapidly with the age, while the fat does not vary materially between the ages of 2 and 15 . Very few people realize how much protein is needed by the very young child, and great errors in diet are made even by those who give the most careful thought to the proper training and feeding of the young. When the diet of an infant of 10 to 12 months old is changed from one of strictly milk, the child is generally given for the next four to ten months a diet composed mostly of starch (mush, potato, bread, rice, sago, etc.), with of course some milk; whereas, it not only needs nitrogenous matter, but is better prepared to digest it. It may be said right here, as no further reference will be made to the subject, that soup does not furnish the needed protein, but that some egg and meat or the juice of rare beef with plenty of milk, combined with the cereals used, would more nearly approach the standard.

The subsistence dietary, No. 13, amounts to very little more than No. 2 , that of a child between 2 and 6 years old; the protein or nitrogenous matter being identical in both cases.

The figures just given in the table represent the amounts of the nutrients actually contained in the different dietaries, but do not give any indication of the total bulk of the food eaten.

In cattle feeding there has to be a certain bulk of dry matter so that the animal may feel satisfied and the digestive processes go on in a normal manner. With man also, for the same reasons, a certain bulk is necessary. Bread, potatoes, vegetables, and similar foods take the place of the coarse fodders in the cattle foods.

The question of rations for cattle is a much simpler one in many respects than for man, for in the latter case there are many circumstances which militate against the getting of reliable data on the subject.

Dr. Rubner states that a diet of bread and water is more endurable than one of fish, eggs, meat, or any other single article of diet. In an experiment with a Bavarian, a diet of bread and water was fed for three days. About 2.5 pounds of bread were consumed per day.

In another experiment with a medical student in Munich, beefsteak, exceedingly well cooked, was used as the diet, but the quantity eaten was less than two pounds daily. The meat, although so well serred, became very distasteful even on the second day.

Division and Composition of Foods. - The human foods are divided into two main classes - the animal and vegetable. The animal contains chiefly, with reference to nutrients, albuminoids with more or less of fat, and are generally designated as nitrogenous foods, while the greater part of the nutriment in vegetable foods is carbohydrates or starchy materials. The exceptions to this are the peas and beans, whose composition includes about 25 per cent of albuminoids, and hence they should be classed as nitrogenous foods. 
It must not be forgotten that while in all foods there is a certain portion which is not digestible, there is, in addition to this, in the foodmaterials as they are found in the market, notably in the animal foods, considerable refuse or waste material, which varies from about 5 per cent in some of the meats to as high as 50 per cent, and consists of bones, skin, etc.

In the vegetable foods this refuse does not amount to so much, and in the cereal part of our diet, practically nothing. In potatoes and cabbage there is about 15 per cent of refuse; in squash, 50 per cent; in turnips, 25 per cent; in apples and grapes, about 25 per cent. Table II shows the proportion of waste material in some of our ordinary foods as we buy them.

\section{TABLE II.}

Conposition of Differext Food-dlaterials.

(Atwater.)

\begin{tabular}{|c|c|c|c|c|c|c|c|c|}
\hline & \multirow{3}{*}{$\begin{array}{l}\text { Refuse. } \\
\text { (Bones, } \\
\text { Shell, } \\
\text { Skin, } \\
\text { etc.) }\end{array}$} & \multicolumn{7}{|c|}{ Edible Portiox. } \\
\hline & & \multirow{2}{*}{ Water. } & \multicolumn{5}{|c|}{ Nutrients. } & \multirow{2}{*}{ 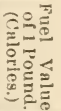 } \\
\hline & & & Total. & Protein. & Fat. & $\begin{array}{l}\text { Carbo- } \\
\text { hydrates }\end{array}$ & $\begin{array}{l}\text { Mineral } \\
\text { Matters. }\end{array}$ & \\
\hline Beef-Rib. & 21.0 & 38.0 & 40.8 & 12.2 & 27.9 & $\cdots$ & .7 & 1,405 \\
\hline Sirloin & 19.5 & 48.3 & 32.2 & 15.0 & 16.4 & -..... & .8 & 970 \\
\hline Veal-shoulder........ & 17.9 & 56.7 & 25.4 & 16.6 & 7.9 & - $\ldots . . .$. & .9 & 640 \\
\hline Mutton-Leg ........ & 18.1 & 50.6 & 31.3 & 15.2 & 15.6 & (........ & .7 & 935 \\
\hline Loin ........ & 15.8 & 41.5 & 42.7 & 12.6 & 29.5 & - . n...... & .6 & 1,480 \\
\hline Pork-Fresh, Shoulder- & 14.6 & 43.0 & 42.4 & 13.6 & 25.0 & ........ & .8 & 1,435 \\
\hline Ham ................ & 11.4 & 36.8 & 51.8 & 14.8 & 34.6 & ....... & 2.4 & 1,735 \\
\hline $\begin{array}{l}\text { Chicken } \\
\text { Turkey }\end{array}$ & 38.2 & 44.6 & 17.2 & 15.1 & 12 & ......... & .9 & 330 \\
\hline $\begin{array}{l}\text { Turkey } \\
\text { Egg (in shell) }\end{array}$ & $\begin{array}{l}32.4 \\
13.7\end{array}$ & $\begin{array}{l}44.7 \\
63.1\end{array}$ & $\begin{array}{l}22.9 \\
232\end{array}$ & 16.1 & 5.9 & (n........ & .9 & 550 \\
\hline Fish-Codfish ................ & $\begin{array}{l}15.7 \\
29.9\end{array}$ & $\begin{array}{l}03.1 \\
58.5\end{array}$ & 11.6 & 10.6 & $\begin{array}{r}10.2 \\
.2\end{array}$ & (n) & .9 & $\begin{array}{l}600 \\
205\end{array}$ \\
\hline Salmon ........ & 35.3 & 40.6 & 24.1 & 14.3 & 8.8 & (2........ & 1.0 & 635 \\
\hline Halibut......... & 17.7 & 61.9 & 20.4 & 15.1 & 4.4 & (......... & .9 & 465 \\
\hline Mackerel ....... & 44.8 & 40.4 & 15.0 & 10.0 & 4.3 & ......... & .7 & 365 \\
\hline Flounder ....... & 66.8 & 27.2 & 6.0 & 5.2 & .3 & ........ & .5 & 110 \\
\hline Oysters (in shell) ...... & 82.3 & 15.4 & 2.3 & 1.1 & .2 & .6 & .4 & 40 \\
\hline Lobsters ............ & 62.1 & 31.0 & 6.9 & 5.5 & .7 & .1 & .6 & 135 \\
\hline
\end{tabular}

The above table shows great variations in the refuse of the different foods represented. In beef the waste is about 20 per eent, very little more than one half that of turkey, and not far from firo cighths the amount given for chicken. This is important in more ways than one, because while the price of chicken is often higher than that of beef, there is more nourishment in the heef, owing to its larger contents of fat, and also, as just stated, hecanse the waste or refuse in boef is only alout one half that of ehieken. Thesame ean be said of turkey. Mutton eontains less waste material than beef, and pork shows a lower pereentage in this respect than mutton.

() flue meats mentioned in the tahle, the protein eontents do not show as wide differences as do the fats; the range for the protein being from 12 to 16 , while that of the fat varies all the way from 29.5 per eent in mutton (loin) to 1.2 in chicken. Henee, wo sece that ehicken would be exeellent for persons wishing a nitrogenous animal-fool associated with the minimum fat. 
Among the fishes the least waste material is found in the halibut, with 17.70 per cent, and the greatest in the flounder, which contains 66.8 per cent; yet the same price would probably have to be paid for each. The average protein content in the fishes is somewhat lower than the corresponding average for the meats. The amount of fat found in fish is small, salmon, with 8.8 , having the maximum, and flounder, with .3 per cent, the minimum. The shell fish all have high percentages of waste material.

Table II is very interesting and quite important in its way, both as regards food value and food economy. It is not, however, in a convenient form for the calculation of dietaries; a difficulty overcome by Tables III and IV, which, respectively, show the amounts in ounces of nutrients per pound, and parts of an ounce per ounce, of the different foods represented. In the tables the data given for the fruits and nuts have been estimated from analyses made by Mr. George E. Colby of this Station, that for California flour and bread from analyses of my own, while the figures for the remaining foods were calculated from data published by Professor Atwater.

Having these tables before us, the making up of dietaries is a very simple matter. It should be said that in these tables the figures for Nos. 1 to 15 , inclusive, include the waste; while for the remainder the edible portion only is represented. 
TABLE III.

Showixg Axounts, in Ouxces, of Nutriexts ix Oxe Pouxd of Differext Foods.

\begin{tabular}{|c|c|c|c|c|c|c|c|}
\hline & \multicolumn{7}{|c|}{ Edible Portion. } \\
\hline & \multirow{2}{*}{ Water. } & \multicolumn{5}{|c|}{ Nutrients (Ounces). } & \multirow{2}{*}{ 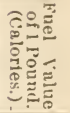 } \\
\hline & & Total. & Protein. & Fat. & $\begin{array}{c}\text { Carbo- } \\
\text { hydrates }\end{array}$ & $\begin{array}{l}\text { Mineral } \\
\text { Matters. }\end{array}$ & \\
\hline 1. Beef-Roast Rib & 6.08 & 6.53 & 1.95 & 4.46 & & .12 & 1.405 \\
\hline 2. Sirloin ... & 7.73 & 5.15 & 2.40 & $\begin{array}{l}7.70 \\
2.62\end{array}$ & & .13 & 970 \\
\hline 3. II utton-Leg -..... & 8.10 & 5.01 & 2.40 & 2.50 & ... & .11 & 935 \\
\hline 4. Loin & 6.64 & 6.84 & 2.02 & 4.72 & - & .10 & 1,480 \\
\hline 5. Veal, Shoulder & 9.07 & 4.06 & 2.66 & 1.26 & - & .14 & 640 \\
\hline 6. Pork-Fresh, Shoulder & 6.88 & 6.78 & 2.17 & 4.48 & ... & .13 & 1,435 \\
\hline Ham ....... & 5.89 & 8.29 & 2.37 & 5.54 & . & .38 & 1,735 \\
\hline 8. Chicken ....... & 7.14 & 2.75 & 2.42 & .19 & .... & .14 & 330 \\
\hline 9. Turkey - & 7.15 & 3.66 & 2.58 & .94 & - & .14 & 550 \\
\hline 10. Eggs (in shell) ... & 10.10 & 3.71 & 1.94 & 1.63 & $\ldots$ & .14 & 655 \\
\hline 11. Fish-Codfish & 9.28 & 1.86 & 1.70 & .03 & - & .13 & 205 \\
\hline 12. Salmon .... & 6.50 & 3.86 & 2.29 & 1.41 & ... & .16 & 635 \\
\hline Halibut & 9.90 & 3.26 & 2.42 & .70 & ........ & .14 & 465 \\
\hline Mackerel.. & 6.46 & 2.40 & 1.60 & .69 & (......... & .11 & 365 \\
\hline Flounder .... & 4.34 & .96 & .83 & .05 & 然 & .08 & 110 \\
\hline 16. Oysters ............. & 13.93 & 2.07 & .96 & .19 & .59 & .32 & 230 \\
\hline 17. Crab ........... & 12.34 & 3.66 & 2.85 & .32 & $-\ldots$. & .49 & 415 \\
\hline 18. Sausage, Bologna .... & 9.98 & 6.02 & 3.01 & 2.53 & & .45 & 1,015 \\
\hline 19. Cheese-Full Cream - & 4.84 & 11.16 & 4.52 & 5.68 & .29 & .67 & 2,070 \\
\hline 20. Skim Milk .. & 6.61 & 9.39 & 6.14 & 1.09 & 1.43 & .74 & 1,165 \\
\hline 21. Milk & 13.92 & 2.08 & .57 & .64 & .75 & .12 & 325 \\
\hline 22. Butter .......... & 1.68 & 14.32 & .16 & 13.60 & .08 & .48 & 3,615 \\
\hline 23. Wheat Flour (California)... & 2.00 & 14.00 & 1.28 & .18 & 12.46 & .08 & 1,627 \\
\hline 24. Grahan Flour (California). & 1.94 & 14.06 & 1.36 & .32 & 12.13 & .25 & 1,650 \\
\hline 25. Oatmeal & 1.22 & 14.78 & 2.42 & 1.13 & 10.91 & .32 & $1, \$ 50$ \\
\hline 26. Cornmeal... & 2.40 & 13.60 & 1.47 & .61 & 11.30 & .22 & 1,645 \\
\hline 27. Rice .................. & 1.98 & 14.02 & 1.18 & .07 & 12.71 & .06 & 1,630 \\
\hline 28. Peas (dried) & 1.97 & 14.03 & 4.27 & .27 & 9.03 & .46 & 1,565 \\
\hline 29. Beans (dried) & 2.02 & 13.98 & 3.70 & .32 & 9.47 & .49 & 1,615 \\
\hline 30. Potatoes-"Irish" & 12.62 & 3.38 & .34 & .02 & 2.86 & .16 & 375 \\
\hline 31. Sweet.... & 11.38 & 4.62 & .24 & .06 & 4.16 & .16 & 530 \\
\hline 32. Carrots & 14.18 & 1.82 & .18 & .06 & 1.42 & .16 & 200 \\
\hline 33. Onions........................ & 14.00 & 2.00 & .23 & .05 & 1.63 & .09 & 225 \\
\hline 34. Green Peas .......... & 12.50 & 3.50 & .70 & .10 & 2.56 & .14 & 405 \\
\hline 35. String Beans ......... & 13.95 & 2.05 & .35 & .06 & 1.51 & .13 & 235 \\
\hline 36. Green Corn & 13.01 & 2.99 & .45 & .18 & 2.27 & .09 & 345 \\
\hline 37. Tomatoes.............. & 15.36 & .64 & .13 & .06 & .40 & .05 & 80 \\
\hline 38. Cabbage ...... & 14.48 & 1.52 & .38 & .07 & .85 & .22 & 155 \\
\hline 39. Sugar & .32 & 15.68 & & & 15.65 & .03 & 1,820 \\
\hline 40. Bread (California) & 5.17 & 10.83 & 1.03 & .27 & 9.39 & .14 & 1,280 \\
\hline 41. Apples (Califoruia).. & 13.31 & 2.69 & .03 & .06 & 2.55 & .05 & 315 \\
\hline 42. Oranges (('aliforniá) & 14.13 & 1.87 & .12 & & .75 & & 219 \\
\hline 43. Prunes (all) (California).... & 12.83 & 3.17 & .14 & & .96 & .07 & 371 \\
\hline 44. A pricots (California) & 13.61 & 2.39 & .17 & & 15 & .07 & $2 \div 0$ \\
\hline 45. Figs (California) ............ & 12.66 & 3.34 & .12 & & 01 & .09 & 390 \\
\hline 46. Grapes (f'alifornia) ........ & 12.82 & $3.1 \mathrm{~s}$ & .20 & & .90 & .08 & 372 \\
\hline 47. Olives (California) & 9.28 & 6.72 & .18 & 4.42 & 1.85 & .27 & 1,404 \\
\hline 48. Walnuts (California) & .45 & 15.55 & 2.28 & 10.50 & 2.61 & .16 & 3,230 \\
\hline 49. Almonds (California)...... &.$\$ 5$ & 15.15 & 2.52 & 8.99 & 3.05 & .29) & 3.060 \\
\hline 50. Peanuts & 1.20 & 14.80 & 4.46 & 6.34 & 3.62 & .38 & 2.619 \\
\hline
\end{tabular}


TABLE IV.

Showing Amounts, in Parts of an Ounce, of Nutrients in One Ounce of DIFFERENT FOODS.

\begin{tabular}{|c|c|c|c|c|c|c|c|}
\hline & \multicolumn{7}{|c|}{ Edible Portion. } \\
\hline & \multirow{2}{*}{ Water. } & \multicolumn{5}{|c|}{ Nutrients (Ounces). } & \multirow{2}{*}{$\begin{array}{c}\text { Fuel } \\
\text { Value } \\
\text { of One } \\
\text { Ounce. }\end{array}$} \\
\hline & & Total. & Protein. & Fat. & $\begin{array}{c}\text { Carbo- } \\
\text { hydrates }\end{array}$ & $\begin{array}{l}\text { Minera1 } \\
\text { Matters. }\end{array}$ & \\
\hline 1. Beef-Roast Rib & .380 & .408 & .122 & .279 & & .007 & 88 \\
\hline 2. Sirloin & .480 & .322 & .150 & .164 & .... & .008 & 61 \\
\hline 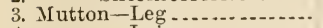 & .506 & .313 & .150 & .156 &.- & .007 & 58 \\
\hline $4 . \quad$ Loin $\ldots \ldots \ldots$ & .415 & .427 & .126 & .295 & $-\ldots$ & .006 & 93 \\
\hline 5. Veal-Shoulder & .567 & .254 & .166 & .079 & -.... & .009 & 16 \\
\hline 6. Pork-Fresh, Shoulder ..... & .430 & 4 & .136 & .280 & - & .008 & 90 \\
\hline 7. Ham & .368 & .5 & .148 & .346 & … & .024 & 108 \\
\hline 8. Chicken & .446 & .1 & .151 & .012 & .... & .009 & 21 \\
\hline 9. Turkey - & .4 & .2 & .161 & .059 & .... & .009 & 34 \\
\hline 10. Eggs (in shell) & .7 & .2 & .149 & .105 & ..... & .008 & 45 \\
\hline $\begin{array}{l}\text { 11. Fish-Codfish } \\
12 .\end{array}$ & .5 & .1 & .106 & .002 & $\ldots$ & .048 & 13 \\
\hline t.- & &. & .143 & .0 & & .010 & 40 \\
\hline 1 & & 4 & .151 & .0 & 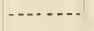 & .009 & 29 \\
\hline $\begin{array}{l}\text { Mackerel } \\
\text { Flounder }\end{array}$ & & 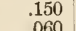 & .100 & .0 & (n) & .007 & 22 \\
\hline 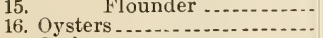 & & 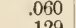 & .0 & & 0 & .005 & 7 \\
\hline 16. Oysters 1 . Crab & & .129 & .0 & .0 & .037 & .020 & 14 \\
\hline 17. Srab Sausage-Bologna & & .2 & .17 & .020 & & .031 & 26 \\
\hline & .6 & $\begin{array}{l}.376 \\
130\end{array}$ & .1 & $\begin{array}{l}.158 \\
.010\end{array}$ & & .03 & 63 \\
\hline 20. Cheese-Full Cream & .302 & .1 & .0 & .0 & .018 & $\begin{array}{l}.007 \\
.042\end{array}$ & \\
\hline 21 . Skim Milk & .413 & 8 & .283 & .355 & .0189 & $\begin{array}{l}.042 \\
.046\end{array}$ & 129 \\
\hline 22. Butter. & .10 & .895 & .010 & .8 & .005 & .030 & $\begin{array}{r}73 \\
226\end{array}$ \\
\hline 23. Wheat Flour & .12 & .875 & .0 & .0 & .779 & .005 & 102 \\
\hline 24. Graham Flour................. & .12 & .8 & .0 & & .758 & .015 & 103 \\
\hline 25. Oatmeal & .076 & .924 & .1 & .0 & .682 & .020 & 106 \\
\hline 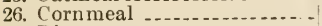 & .1 & .8 & .0 & .0 & .706 & .014 & 103 \\
\hline 27. Rice & 1 & .8 & .0 & .0 & .794 & .001 & 102 \\
\hline 28. Peas (dried) ........................ & .123 & .877 & .26 & .017 & .564 & .029 & 98 \\
\hline 29. Beans (dried) & .126 & .874 & .231 & .020 & .592 & .031 & 101 \\
\hline 30. Potatoes-"Irish" & .789 & .211 & .021 & .001 & .179 & .010 & 23 \\
\hline 31. Sweet_.......... & .711 & .289 & .0 & .0 & .260 & .010 & 33 \\
\hline 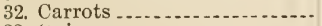 & .886 & .114 & .01 & .0 & .089 & .010 & 13 \\
\hline (2) & .875 & .125 & .0 & .0 & .102 & .006 & 14 \\
\hline 34. Green Peas........ & .781 & .2 & .0 & .0 & .016 & .009 & 25 \\
\hline 35. String Beans ...... & .87 & .1 & .0 & .004 & .094 & .008 & 15 \\
\hline 36. Green Corn ..................... & .81 & .187 & .028 & .011 & 14.014 & .0 & 22 \\
\hline 37. Tomatoes & .960 & .040 & .0 & .004 & .025 & 3 & 5 \\
\hline 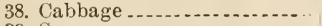 & .905 & .0 & .024 & .004 & .053 & .0 & 10 \\
\hline 39. Sugar & .02 & .980 & $\ldots-$ & $\ldots$ & .978 & .06 & 114 \\
\hline 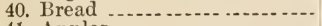 & .32 & .677 & .06 & .0 & .587 & .009 & 80 \\
\hline 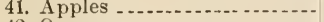 & .83 & .1 & .002 & .004 & .159 & .003 & 20 \\
\hline 42. Oranges & .880 & .120 & .008 & & 112 & & 14 \\
\hline 43. Prunes (all) & .800 & .200 & .009 & & 187 & .005 & 23 \\
\hline 44. A pricots & .850 & .150 & .010 & & 135 & .005 & 18 \\
\hline 45. Figs ............. & .790 & .210 & .015 & & 189 & .006 & 24 \\
\hline 46. Grapes & .800 & .200 & .013 & & 182 & .005 & 23 \\
\hline 47. Olives & .580 & .420 & .011 & .276 & .116 & .017 & 88 \\
\hline 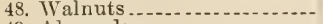 & .025 & .975 & .143 & .659 & .163 & .010 & 202 \\
\hline 49. Almonds ...... & .053 & .947 & .176 & .562 & .191 & .018 & 191 \\
\hline 50. Peanuts ...... & .080 & .920 & .280 & .400 & .230 & .020 & 161 \\
\hline
\end{tabular}

To illustrate the method of forming a dietary, any of the standards mentioned in Table I could be used. An excellent one is No. 10 as adopted.by Prof. Atwater, for a man at moderate work, deduced from extensive comparisons of many dietaries.

The standard is .28 pounds of protein, or flesh-forming ingredients, .28 
pounds of fat, and .99 pounds of carbohydrates or starchy material, with a fuel value of 3,500 calories; or expressed in ounces, 4.48 ounces of protein, 4.48 ounces of fat, and 15.84 ounces of earbohydrates.

Suppose we have mutton, salmon, potatocs, butter, bread, and graham flour to choose from. The first thing to do is to glance at the compo:ition of these materials in the tables, and to make a rough estimate at the amounts, in pounds or ounces, of each needed, bearing in mind the usual proportions, approximately, of such things consumed in the ordinary houschold.

A little practice will insure an estimate not very far from the correct amount. The next step is to calculate the proportion of the different ingredients in the quantities estimated and compare them with the standard adopted, and to make such corrections in the original estimate as the comparison shows to be necessary.

To return to our proposed dietary, we will suppose that we can eat 8 ounces of mutton (loin). Turning to Table IV we find mutton (loin) numbered 4 , and we multiply by 8 the figures given for one ounce, and write them down. After doing the same for the other articles, we have the following little table:

\begin{tabular}{|c|c|c|c|c|c|c|}
\hline $\begin{array}{l}\text { No. in } \\
\text { Table. }\end{array}$ & $\begin{array}{l}\text { Am't Used. } \\
\text { Ounces. }\end{array}$ & Material. & Protein. & Fat. & $\begin{array}{c}\text { Carbohy- } \\
\text { drates. }\end{array}$ & $\begin{array}{c}\text { Fuel } \\
\text { Value. }\end{array}$ \\
\hline \multirow[t]{2}{*}{$\begin{array}{r}4 \\
12 \\
24 \\
40 \\
22 \\
30\end{array}$} & $\begin{array}{c}8 \\
8 \\
3 \\
18 \\
1.8 \\
8\end{array}$ & \multirow[t]{2}{*}{$\begin{array}{l}\text { Mitton } \\
\text { Salmon } \\
\text { Graham Flour } \\
\text { Bread } \\
\text { Butter } \\
\text { Potatoes }\end{array}$} & $\begin{array}{l}1.01 \\
1.14 \\
0.26 \\
1.16 \\
0.02 \\
0.17\end{array}$ & $\begin{array}{l}2.36 \\
0.70 \\
0.06 \\
0.30 \\
1.53 \\
0.01\end{array}$ & $\begin{array}{r}2.28 \\
10.56 \\
0.01 \\
1.43\end{array}$ & $\begin{array}{r}740 \\
315 \\
309 \\
1,440 \\
407 \\
1 \times 8\end{array}$ \\
\hline & 46.8 & & 3.76 & 4.96 & $14.2 \mathrm{~s}$ & 3,402 \\
\hline
\end{tabular}

The above figures show us that the protein is lacking in the dietary, also that the fuel value is slightly below the standard. To remedy this defect we add some one article specially rich in protein; suppose we take about $1 \frac{7}{8}$ ounces of skim-milk cheese (No. 21 in Table IV). Calculating this out for the different nutrients, and adding to the above we have-

\begin{tabular}{|c|c|c|c|c|}
\hline & Protein. & Fat. & $\begin{array}{l}\text { Carbohy- } \\
\text { drates. }\end{array}$ & $\begin{array}{c}\text { Fuel } \\
\text { Value. }\end{array}$ \\
\hline $\begin{array}{l}\text { No. } 21-17 / \text { ounces skim-milk cheese ... } \\
\text { Original dietary . }\end{array}$ & $\begin{array}{l}0.72 \\
3.76\end{array}$ & $\begin{array}{l}0.13 \\
4.96\end{array}$ & $\begin{array}{r}0.17 \\
14.28\end{array}$ & $\begin{array}{r}135 \\
3,402\end{array}$ \\
\hline Completed dietary........ & 4.48 & 5.09 & 14.45 & 3,537 \\
\hline
\end{tabular}

Which is practically identical with our standard as regards protein and fuel value. This is a good illustration of the fact that fat and carbolyydrates can replace each other in any dictary or ration in the proportion of 1 of the former to 2.25 of the latter and not alter its fuel value. ()ur standard ealls for 4.48 ounces of fat; we have 5.09. The differenee, 0.ti1, multiplied by 2.25 amounts to 1.37 , which almost equals the differeneer (1.39) between 15.84 , the figure named for earbohydrates in our standard, and 14.45, the quantity given in our assumed dietary.

For a second dietary suppose we take sirloin steak, butter, milk, potatoes, and bread. Proceeding as before, we have- 


\begin{tabular}{|c|c|c|c|c|c|c|}
\hline No. & $\begin{array}{l}\text { Am't Used. } \\
\text { Ounces. }\end{array}$ & Material. & Protein. & Fat. & $\begin{array}{c}\text { Carbohy- } \\
\text { drates. }\end{array}$ & $\begin{array}{c}\text { Fuel } \\
\text { Volue. }\end{array}$ \\
\hline $\begin{array}{r}2 \\
22 \\
19 \\
30 \\
40\end{array}$ & $\begin{array}{r}14 \\
2 \\
28 \\
16 \\
16\end{array}$ & $\begin{array}{l}\text { Steak } \\
\text { Butter } \\
\text { Milk } \\
\text { Potatoes } \\
\text { Bread }\end{array}$ & $\begin{array}{r}2.10 \\
.02 \\
.99 \\
.34 \\
1.03\end{array}$ & $\begin{array}{r}2.33 \\
1.70 \\
1.12 \\
.27\end{array}$ & $\begin{array}{r}.02 \\
1.28 \\
2.86 \\
9.39\end{array}$ & $\begin{array}{r}854 \\
452 \\
570 \\
375 \\
1,2 \backsim 0\end{array}$ \\
\hline & 76 & & 4.48 & 5.42 & 13.55 & 3,531 \\
\hline
\end{tabular}

This happens to be a well-balanced dietary; that is, one in which the nitrogenous and non-nitrogenous materials are in the proper proportions.

As another example, let us take oatmeal, bread, eggs, sweet potatoes, butter, sugar, chicken, and rice:

\begin{tabular}{|c|c|c|c|c|c|c|c|}
\hline $\begin{array}{c}\text { Number } \\
\text { in } \\
\text { Table. }\end{array}$ & $\begin{array}{l}\text { Amount } \\
\text { Used. } \\
\text { Oulices. }\end{array}$ & Material. & $\begin{array}{l}\text { Total Nu- } \\
\text { trients. }\end{array}$ & Protein. & Fat. & $\begin{array}{c}\text { Carbo- } \\
\text { hydrates. }\end{array}$ & $\begin{array}{c}\text { Fuel } \\
\text { Value. } \\
\text { Calories. }\end{array}$ \\
\hline $\begin{array}{r}25 \\
40 \\
10 \\
31 \\
22 \\
39 \\
8 \\
8 \\
27\end{array}$ & $\begin{array}{r}4 \\
16 \\
4 \\
8 \\
3 \\
3 \\
8 \\
2\end{array}$ & $\begin{array}{l}\text { Oatmeal } \\
\text { Bread } \\
\text { Eggs } \\
\text { Sweet Potatoes... } \\
\text { Butter ... } \\
\text { Sugar } \\
\text { Chicken } \\
\text { Rice }\end{array}$ & $\begin{array}{r}3.68 \\
10.83 \\
.93 \\
2.31 \\
2.69 \\
2.94 \\
1.30 \\
1.75\end{array}$ & $\begin{array}{r}.64 \\
1.03 \\
.48 \\
.12 \\
.03 \\
1.21 \\
.15\end{array}$ & $\begin{array}{r}.32 \\
.27 \\
.41 \\
.03 \\
2.55 \\
.09 \\
.01\end{array}$ & $\begin{array}{r}2.72 \\
9.39 \\
2.08 \\
.01 \\
2.93 \\
1.59\end{array}$ & $\begin{array}{r}469 \\
1,280 \\
164 \\
26.5 \\
678 \\
342 \\
165 \\
204\end{array}$ \\
\hline & 48 & & 26.43 & 3.66 & 3.68 & 18.72 & $3,55 \mathrm{~s}$ \\
\hline
\end{tabular}

This is a dietary with about the right caloric value, but is lacking in the muscle-forming element, as seen by the low figure for protein. Yet it is not by any means an uncommon one, and most people would consider themselves well fed on it. The lack of protein could be very easily remedied by substituting beans for the rice, as this change would increase the nitrogenous element, and, at the same time, decrease the amount of starch. If beans are not relished, and rice is preferred with chicken, the same result may be obtained by reducing the amount of sweet potato to one half, and in the place of it substituting a concentrated soup of dried peas. Thus, in many ways could this incorrect dietary (according to our standard) be regulated, without making any very radical change.

In order to show that it is not necessary to have any great variety to get the proper proportions, let us compare the two following lists of foods, given'by Atwater. Suppose one man eats in a single day, of steak, 13 ounces; butter, 3 ounces; potatoes, 6 ounces; and bread, 22 ounces. This constitutes a well-balanced dietary. But the man who takes as his dietary pork chops, 8 ounces; liver, 8 ounces; one egg; butter, 3 ounces; milk, one cup; potatoes, 12 ounces; turnips, 4 ounces; corn, 4 ounces; oatmeal, 1 ounce; rice, 1 ounce; wheat flour, 4 ounces; graham flour, 2 ounces; and sugar, 3 ounces, would have a dietary no better in any way, as they both contain the same amount of protein, 4.48 ounces, with 3,500 calories; but the latter might prove more pleasing to the palate, which is worth considering. At the same time, it might also prove more expensive, or harder on the stomach-points which must not be lost sight of. One of our Berkeley students is living on a 
small loaf of bread, a pound of steak, and four ounces of butter per day. This is a meager dietary, though seemingly like the one just called correct; but the first diet had potatoes in addition, and probably more hread. The composition of his dict is as follows:

\begin{tabular}{|c|c|c|c|c|c|c|}
\hline $\begin{array}{l}\text { No. in } \\
\text { Table. }\end{array}$ & $\begin{array}{l}\text { Am't Used. } \\
\text { Ounces. }\end{array}$ & Material. & Protein. & Fat. & $\begin{array}{c}\text { Carbo- } \\
\text { hydrates. }\end{array}$ & $\begin{array}{c}\text { Fuel } \\
\text { Value. }\end{array}$ \\
\hline \multirow[t]{2}{*}{$\begin{array}{r}2 \\
40 \\
22\end{array}$} & $\begin{array}{r}16 \\
16 \\
4\end{array}$ & \multirow[t]{2}{*}{$\begin{array}{l}\text { Steak } \\
\text { Bread } \\
\text { Butter }\end{array}$} & $\begin{array}{r}2.40 \\
1.03 \\
.04\end{array}$ & $\begin{array}{r}2.62 \\
.27 \\
3.40\end{array}$ & $\begin{array}{r}9.39 \\
.02\end{array}$ & $\begin{array}{r}970 \\
1,280 \\
904\end{array}$ \\
\hline & 36 & & 3.47 & 6.29 & 9.41 & 3,154 \\
\hline
\end{tabular}

The subsistence dietary, No. 13 in Table I, would consist of about 18 ounces of bread and 6 of meat, as follows:

\begin{tabular}{|c|c|c|c|c|}
\hline & Protein. & Fat. & $\begin{array}{c}\text { Carbo- } \\
\text { hydrates. }\end{array}$ & $\begin{array}{c}\text { Fuel } \\
\text { Value. }\end{array}$ \\
\hline \multirow[t]{2}{*}{18 ounces bread 6 ounces meat } & $\begin{array}{r}1.16 \\
.90\end{array}$ & $\begin{array}{l}.30 \\
.96\end{array}$ & 10.56 & $\begin{array}{r}1,440 \\
360\end{array}$ \\
\hline & 2.06 & 1.26 & 10.56 & 1,800 \\
\hline
\end{tabular}

The army ration of the United States is a good illustration of the fact that although several of the foods seem to have the same composition they cannot be used as substitutes for each other. For instance, the meat ration consists of 22 ounces salt beef, or 12 of salt pork or bacon, or 12 of corned beef (fresh,or canned), or 20 of fresh beef, or 14 of dried fish, or 18 of pickled fish. The ealoric value of these meats vary greatly, that of 20 ounees fresh beef being 1,700 with 8.16 ounces of protein, while 12 ounces corned beef has only 1,200 calories with about 5.5 ounces of protein. The same may be said of the cereal part of the ration, thus proving that these materials connected by "or" are not always equivalents.

The following is an example of a strictly vegetable dict:

\begin{tabular}{|c|c|c|c|c|c|c|}
\hline $\begin{array}{l}\text { No in } \\
\text { Table. }\end{array}$ & $\begin{array}{l}\text { Am't Used. } \\
\text { Ounces. }\end{array}$ & Material. & Protein. & Fat. & $\begin{array}{l}\text { Carbohy- } \\
\text { drates. }\end{array}$ & $\begin{array}{c}\text { Fuel } \\
\text { Value. }\end{array}$ \\
\hline \multirow[t]{2}{*}{$\begin{array}{l}29 \\
30 \\
36 \\
40 \\
27 \\
25\end{array}$} & $\begin{array}{r}5 \\
16 \\
4 \\
15 \\
4 \\
4\end{array}$ & $\begin{array}{l}\text { Beans } \\
\text { Potatoes } \\
\text { Corn } \\
\text { Bread } \\
\text { Rice } \\
\text { Oatmeal }\end{array}$ & $\begin{array}{r}1.16 \\
.34 \\
.12 \\
1.16 \\
.30 \\
.61\end{array}$ & $\begin{array}{l}.10 \\
.02 \\
.05 \\
.30 \\
.02 \\
.28\end{array}$ & $\begin{array}{r}2.96 \\
2.86 \\
.57 \\
10.56 \\
3.18 \\
273\end{array}$ & $\begin{array}{r}505 \\
375 \\
88 \\
1,440 \\
408 \\
424\end{array}$ \\
\hline & 51 & & 3.69 & .77 & 22.86 & 3,240 \\
\hline
\end{tabular}

This dietary, while fully up to the average in amomnt of food-1naterial, is deficient in protein and fuel value, thus showing that it would he a somewhat diffieult matter to ohtain the proper amsomt of protein and the right calorie value from as strictly vegetable diet. It must not he lost sight of that not only is the protein low, lut that the amomnt prexent would not be egual in nutritive value to the same quantity derived from animal foods, owing to the higher digestion eorflecient of protein possessed loy animal foods. The lack of protein or allominoids and fat in the above 
ration could be remedied by the use of nuts, which are rich in both these ingredients.

Caution, however, must be used when nuts constitute part of the dietary, because of the concentrated form in which the nutrients are found in these food materials.

The richest of the nuts represented in the table, with respect to protein, is the peanut (No. 49), which is analogous, botanically, to the bean. It does not contain as much fat as either the walnut or almond, but has the great advantage of being much cheaper in price.

It will be seen by examining the data given for fresh fruits that it would require a very large bulk and amount of these articles of food to yield a sufficient proportion of nutrients. Dried fruits contain about three times the percentage of nutrients that are found in fresh fruits, and are therefore more available in the construction of dietaries.

Many more dietaries could be calculated from the tables, but the few examples are sufficient to give an idea of the method to be employed by any who intend to make use of them in properly regulating either their own diet or that of others.

A careful study of the tables is recommended to those who appreciate the importance of the subject, both from the nutritive and the economic standpoint. Of course individual tastes and idiosyncrasies must be considered in this connection, as it will not do to override these for the sake of conforming to any preconceived ideas.

It must never be forgotten that while the nearest approach to a normal dietary as expressed by the above data should be aimed at, it by no means follows that a dietary correctly proportioned according to the above data can be successfully used in every particular case. 




THIS BOOK IS DUE ON THE LAST DATE STAMPED BELOW

AN INITIAL FINE OF 25 CENTS WILL BE ASSESSED FOR FAILURE TO RETURN THIS BOOK ON THE DATE DUE. THE PENALTY WILL INCREASE TO 50 CENTS ON THE FOURTH DAY AND TO \$1.00 ON THE SEVENTH DAY OVERDUE.

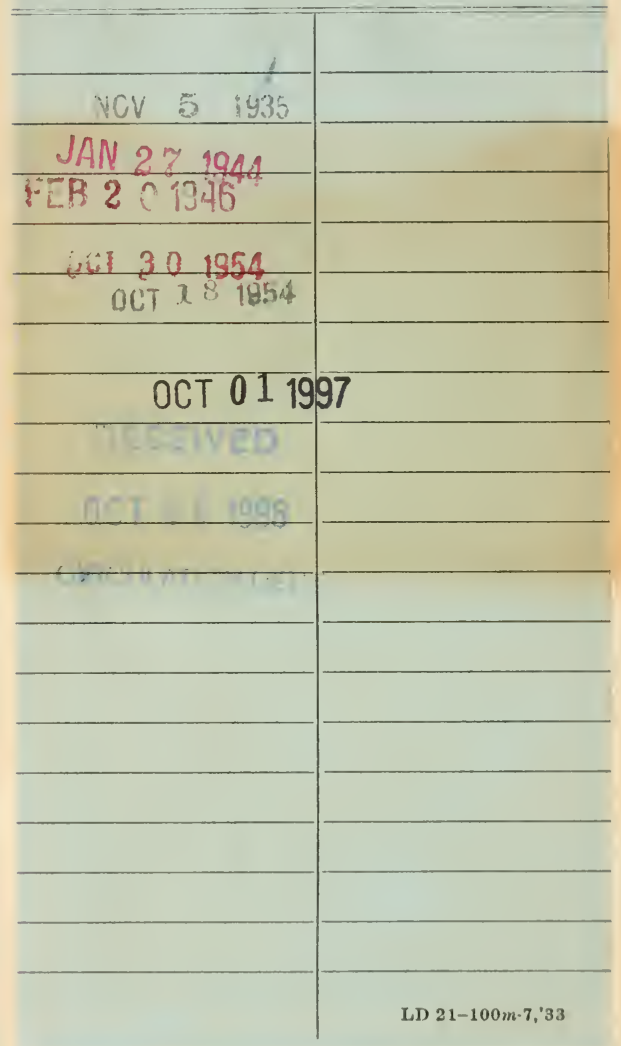


U. C. BERKELEY LIBRARIES

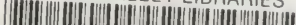

. C056108236

\section{9}

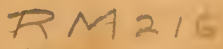

UNIVERSITY OF CALIFORNIA LIBRARY 
